Niniejsza publikacja jest dostępna na licencji Creative Commons. Uznanie autorstwa-Użycie niekomercyjne-Bez utworów zależnych 3.0 Polska. Pewne prawa zastrzeżone na rzecz autora. Zezwala się na wykorzystanie publikacji zgodnie z licencja - pod warunkiem zachowania niniejszej informacji licencyjnej oraz wskazania autora jako właściciela praw do tekstu. Treść licencji jest dostęna na stronie: http://creativecommons.org/licenses/by-nc-nd/3.0/pl/

Lingwistyka Stosowana 21: 1/2017, 203-206

\title{
Hans-Jürgen HANTSCHEL, Michaela BRINITZER, Sandra KROEMER, Monika MÖLLER-FRORATH, Lourdes ROS, DaF unterrichten: Basiswissen Didaktik Deutsch als Fremd- und Zweitsprache, Verlag Klett, 2013, 184 str.
}

Recenzowana publikacja stanowi w zamyśle autorów podręcznik dla studentów studiów nauczycielskich, a także zawodowo pracujących nauczycieli języka niemieckiego jako obcego (Deutsch als Fremdsprache) lub jako języka drugiego (Deutsch als Zweitsprache). Podręcznik może także służyć jako uzupełnienie teoretycznej wiedzy nabytej podczas kursów kwalifikacyjnych uprawniających do prowadzenia zajęć językowych z migrantami. Dostarcza on podstawowej wiedzy w najważniejszych obszarach tematycznych związanych z nauczaniem języka niemieckiego. Punkt ciężkości położony jest przy tym jednak wyraźnie na przekazaniu wskazówek praktycznych, wynikających z doświadczenia zawodowego samych autorów.

Publikacja przekonuje jasnym układem i przejrzystą strukturą treści. W 14 rozdziałach kolejno omówione zostały kluczowe zagadnienia dotyczące rozwijania sprawności językowych (sprawności mówienia, słuchania, czytania i pisania w rozdziałach 1-4), w dalszej kolejności kształcenia kompetencji językowych (kompetencji leksykalnej, gramatycznej i fonetycznej odpowiednio w rozdziałach 5-7), ponadto kwestie odnoszące się do innych zasadniczych aspektów i zasad nowoczesnego nauczania języka obcego (autonomia uczącego się, indywidualizacja procesu nauczania, strategie uczenia się - rozdziały 10 i 11) oraz zagadnienia planowania dydaktycznego i oceniania wyników kształcenia w rozdziałach 13 i 14. Uzupełnienie treści podręcznika stanowi rejestr haseł kluczowych i wykaz aktywności (Verzeichnis der Aktivitäten), będący zestawieniem gier i zabaw dydaktycznych omawianych w poszczególnych rozdziałach.

Ciekawym zabiegiem kompozycyjnym zastosowanym przez autorów jest przeplatanie treści merytorycznych cytatami zaczerpniętymi z wypowiedzi nauczycielipraktyków, do których czytelnik może odnieść własne doświadczenia i przemyślenia. Wypowiedzi te, dotyczące istotnych i typowych problemów praktyki szkolnego nauczania języków obcych, skłaniają do indywidualnej refleksji, mogą też być podstawą wymiany myśli czy dyskusji. Z kolei kluczowe hasła umieszczone na marginesie bocznym dobrze porządkują i dzielą treści znacząco ułatwiając orientację $\mathrm{W}$ treści i lekturę. Każdy rozdział wieńczy rekapitulacja najważniejszych informacji w formie wypunktowanej listy.

Poszczególne rozdziały rozpoczyna blok informacyjny wprowadzający w dany zakres tematyczny, po którym następuje przedstawienie serii wskazówek, idei, sugestii i pomysłów praktycznych do wykorzystania na lekcji języka niemieckiego. Zaprezentowanie ich jednak bez szerszego kontekstu, bez usytuowania w bardziej 
skonkretyzowanych specyficznych warunkach bliżej określonej jednostki lekcyjnej, czy chociażby określenia grupy docelowej może nie stanowić dla czytelnika nie dysponującego doświadczeniem wydatnej pomocy.

Pod względem doboru treści publikację należy ocenić pozytywie, chociaż odczuwalny jest brak szerszego omówienia bardziej przeglądowych treści, takich jak zaledwie wzmiankowany we wstępie - Europejski System Opisu Kształcenia Językowego (ESOKJ) (H. Komorowska 2003), jak i bardziej szczegółowe przedstawienie zarówno ogólnych jak i kierunkowych celów kształcenia językowego. Czytelnik uzyskałby w ten sposób szerszą perspektywę postrzegania procesu glottodydaktycznego i lepszy wgląd w zewnętrze jego uwarunkowania.

Również zawarte $\mathrm{w}$ tytule rozróżnienie dwóch pojęć, a mianowicie nauczania niemieckiego jako języka obcego i jako języka drugiego, nie znajduje szerszego omówienia w treści publikacji. Nauczanie niemieckiego jako języka obcego oznacza nauczanie danego języka w warunkach zinstytucjonalizowanych, będące procesem sterowanym i silnie zorientowanym na pracę z tekstem. Nauczanie niemieckiego jako języka obcego ma na celu osiągnięcie wysokiego poziomu biegłości. Pod pojęciem niemieckiego jako języka drugiego języka rozumie się natomiast nabywanie języka bez instrukcji, w warunkach naturalnej komunikacji (G. Kniffka/ G. SiebertOtt 2007: 15). Chociaż granice między $D a F$ i $D a Z$ nie zawsze są łatwe do uchwycenia, jest to zagadnienie, którego szersze omówienie stanowiłoby cenne dopełnienie treści podręcznika.

Pewien niedosyt pozostaje po lekturze rozdziału 12 Medien und Aktivitätenrepertoire, omawiającego zdawkowo, na zaledwie trzech stronach (s.142-144) tak bardzo aktualną problematykę stosowania w glottodydaktyce nowoczesnych technologii informacyjno-komunikacyjnych. Autorka tego rozdziału dostarcza czytelnikowi jedynie garść bardzo ogólnych informacji, w większości powszechnie znanych i niespornych, wskazując głównie dość schematycznie na pozytywy stosowania nowoczesnych mediów, takich jak Internet, rzutnik multimedialny i tablica interaktywna. Podobny zarzut sformułować należy w odniesieniu do rozdziału 6 Grammatik, którego skromna objętość skutkuje pominięciem pierwszorzędowych kwestii, takich jak specyfika indukcyjnego, dedukcyjnego i mieszanego sposobu prezentacji treści gramatycznych, progresja ćwiczeń gramatycznych, rola terminologii gramatycznej, rozróżnienie gramatyki lingwistycznej i pedagogicznej.

Znaczący postęp technologiczny ostatnich dekad umożliwił łatwiejsze i szersze stosowanie materiału audiowizualnego w nauczaniu, jednak kwestii pracy z filmem jako tekstem audiowizualnym poświęcony został zaledwie jeden kilkuzdaniowy akapit (s. 26). Z kolei w rozdziale 13 Unterrichtsplanung zabrakło choć hasłowego odnotowania typowych i obecnie powszechnie stosowanych modeli planowania lekcji takich jak model PPP (J. Harmer 2001), model zadaniowy (J. Willis 1998) oraz model pre-, while-, post- (H. Komorowska 2005), jak też wskazania na coraz bardziej popularne innowacyjne formy planowania lekcji, jak tzw. odwrócona lekcja (flipped lesson) czy też tzw. użycie wyprzedzajace (vorwegnehmender Gebrauch) (K. Ende/I. Mohr 2013). 
Nieuzasadnione $\mathrm{w}$ tej sytuacji wydaje się nieproporcjonalnie szerokie i dogłębne potraktowanie kwestii fonetyki (rozdział 7, s. 82-94), która z punktu widzenia dydaktycznego, choć istotna, nie stanowi jednak problematyki o fundamentalnym znaczeniu. Uzupełnieniem treści podręcznika jest załączona płyta DVD zawierająca obszerny wywiad z ekspertem w dziedzinie nauczania języka niemieckiego, Sandrą Kroemer, która dogłębnie i wnikliwie wyjaśnia kwestie artykulacji i przedstawia konkretne ćwiczenia dla poprawnej intonacji w języku niemieckim.

Cenne informacje natury ogólniejszej, dotyczące szeroko pojętej komunikacji językowej, znajdzie czytelnik w rozdziale 1 Sprechen. Uwrażliwiają one odbiorcę na kluczową rolę sprawności mówienia w komunikacji, wskazują na specyfikę komunikacji ustnej, dostarczają różnorodnych informacji z zakresu analizy języka mówionego i uzasadniają w ten sposób wyczerpująco priorytetowe znaczenie sprawności mówienia w nauczaniu języków obcych. W pozostałych rozdziałach poświęconych rozwijaniu sprawności językowych dominuje podejście komunikacyjne i zorientowane na działanie językowe uczącego się. Autorzy akcentują przy tym wyraźnie potrzebę wdrażania ucznia do coraz większej aktywności, autonomii, przejmowania kontroli nad procesem uczenia się języka obcego, a tym samym sterowania nim zgodnie z własnymi indywidualnymi predyspozycjami.

W kolejnych rozdziałach poświęconych rozwijaniu kompetencji językowych treści merytoryczne przeplatane są systematycznie cennymi informacjami i uwagami z zakresu bodowy i funkcjonowania mózgu, pamięci, leksykonu mentalnego, jak i z zakresu psychologii poznawczej. Dają one czytelnikowi niezbędną naukową podstawę uzasadniającą konkretne działania dydaktyczne nauczyciela i stanowią niewątpliwie silny punkt recenzowanej publikacji. Treści w powyższych rozdziałach są ponadto dobrze zwizualizowane przykładami praktycznymi. W tej części publikacji uwagę zwraca zaakcentowanie, a tym samym uwrażliwienie czytelnika na typowe błędy metodyczne popełniane przy rozwijaniu kompetencji leksykalnej i gramatycznej.

W części poświęconej planowaniu dydaktycznemu i prowadzeniu zajęć dydaktycznych, na którą składają się rozdziały 8-14, omówione zostały w szczególności takie zagadnienia, jak: formy socjalne stosowane podczas lekcji, możliwości i sposoby indywidualizowania procesu nauczania, uczenie się uczenia - czyli znaczenie znajomości i umiejętnego stosowania strategii uczenia się. Podczas gdy strategie metakognitywne zostały tylko wspomniane, znacznie dogłębniej autorzy omówili strategie kognitywne (strategie pamięciowe, strategie pracy $\mathrm{z}$ tekstem). Każdy z rozdziałów tej części bogaty jest w przykłady ćwiczeń, gier i zabaw dydaktycznych. Gruntownie i wieloaspektowo ukazana została też kwestia doboru, adaptacji i korzystania $\mathrm{z}$ podręcznika wiodącego w nauczaniu. Autorzy tego rozdziału wnikliwie omawiają poszczególne komponenty podręcznika, wskazując przy tym na obudowanie internetowe podręcznika, jako dodatkowy materiał dostępny w Internecie zarówno dla nauczyciela, jak i uczniów.

Dokładniejsza analiza wartości merytorycznej podręcznika wykazuje, iż autorzy wprawdzie w sposób umiejętny i kompetentny referują poszczególne zagadnienia, jednak nie stosują konsekwentnie przyjętego już w literaturze przedmiotu i uznanego aparatu pojęciowego, co z jednej może utrudnić czytelnikowi odbiór treści, z 
drugiej zaś nie pozwala mu na dalsze samodzielne pogłębianie i studiowanie danej tematyki bez znajomości podstawowych terminów i haseł. I tak na przykład w rozdziale 2 Hören autorzy mówią o fazowym przebiegu pracy z tekstem słuchanym, nie stosują przy tym powszechnie znanych określeń, czy to w wersji niemieckojęzycznej (vor dem Hören, während des Hörens, nach dem Hören), czy angielskojęzycznej (pre-, while-, after- listening activities). Istotnym elementem treningu słuchania jest wdrażanie uczniów do świadomego stosowania strategii percepcji tekstu. Kwestia ta jednak nie została podjęta ani w odnośnym rozdziale 2 Hören, ani w rozdziale 3 Lesen, ani też $\mathrm{w}$ poświęconym wyłącznie strategiom uczenia się rozdziale 11 . W przypadku progresji treści gramatycznych sygnalizowanej na stronie 80 nie znajdujemy tu odpowiednio kluczowych pojęć, takich jak progresja liniowa i progresja koncentryczna (G. Neuner/H. Hunfeld 1993: 91), które lepiej wyjaśniłyby czytelnikowi istotę zagadnienia.

Ten napisany z perspektywy doświadczonych nauczycieli praktyczny przewodnik z pewnością dobrze wyjaśni czytelnikowi podstawy skutecznego nowoczesnego nauczania języka niemieckiego. Co prawda autorzy poszczególnych rozdziałów przywołują teorie i tezy uznane $\mathrm{w}$ glottodydaktyce, jednak podręcznik stanowi głównie odbicie ich własnych przemyśleń i doświadczeń Pozycja ta jest więc w ocenie recenzenta raczej prezentacją autorskiego podejścia do nauczania. W podsumowaniu należy stwierdzić, iż mimo wielu zalet, czytelnik oczekujący dokładniejszego, pogłębionego omówienia teoretycznych podstaw i zasad metodyki nauczania języków obcych prawdopodobnie nie będzie w pełni usatysfakcjonowany.

\section{Bibliografia}

Ende, K./ Mohr, I./ Kleppin, K./ Grotjahn, R. (2013), DLL6: Curriculare Vorgaben und Unterrichtsplanung - Buch mit DVD: Fort- und Weiterbildung weltweit. Langenscheidt.

Harmer, J. (2001), The practice of English language teaching. Pearson Education Limited. London.

Kniffka, G./Siebert-Ott, G. (2007), Deutsch als Zweitsprache. Lehren und Lernen. Schöningh.

Komorowska, H. (red.) (2003), Europejski system opisu kształcenia językowego: uczenie sie, nauczanie, ocenianie. Warszawa.

Komorowska, H. (2005), Metodyka nauczania języków obcych. Fraszka Edukacyjna Warszawa.

Neuner, G./ Hunfeld, H. (1993), Methoden des fremdsprachlichen Deutschunterrichts. Eine Einführung. Fernstudieneinheit 4. Langenscheidt, Kassel, München, Tübingen..

Willis, J. (1996), A Framework for Task-Based Learning. Harlow. Longman Pearson Education.

Renata CZAPLIKOWSKA

Uniwersytet Pedagogiczny im. Komisji Edukacji Narodowej w Krakowie 